\title{
Neil Coffee
}

\section{Intertextuality as Viral Phrases: Roses and Lilies}

Abstract: This article addresses the phenomenon of "viral intertextuality," or instances of distinct language that appear serially over multiple literary works. It demonstrates how current digital methods make instances of viral intertextuality much easier to detect. It argues for the value of reading such chains of similar phrases together. And it points toward possible improvements in digital detection and analysis methods that would further facilitate this kind of reading. The illustrative example is Vergil's description of Lavinia's blush at Aeneid 12.67-69, along with its predecessor and successor passages.

\section{Introduction}

Classicists often regard intertextuality as a relationship between two short pieces of text in two different works, following from the tradition of finding loci similes. ${ }^{1}$ But not always. The study of window references, for one, considers a receiving text that borrows from another one, which itself borrows from a previous one. ${ }^{2}$ The question this article poses is: what happens if we extend our consideration from the short span studied in a window reference to the long, varied life of a piece of language? Scholars of reception studies have proposed developing reception histories for individual texts. ${ }^{3}$ Can we possibly, and profitably, develop long histories of short sections of text?

A simple answer would be, "yes," since scholars have already done it. Consider Sergio Audano's 2012 book, Classici lettori di classici: da Virgilio a Marguerite Yourcenar. ${ }^{4}$ Audano traces the legacy of two Vergilian phrases. The first is Vergil's praise of a civilized life, with the phrase inventas aut qui

1 For an annotated bibliography on the study of classical intertextuality, see Coffee (2012). I would like to thank Cari Haas for her assistance in preparing this article. This work has been made possible in part by a major grant from the National Endowment for the Humanities Office of Digital Humanities for the Tesserae Intertext Service project.

2 (Thomas 1986, 188).

3 (Martindale 2006, 5). This whole volume (Martindale and Thomas 2006), along with Brockliss, Chaudhuri et al. (2012), provides good surveys of recent work on classical reception. 4 (Audano 2012).

Neil Coffee, State University of New York at Buffalo

Ә Open Access. (C) 2019 Neil Coffee, published by De Gruyter. (cc) BY-NC-ND This work is licensed under a Creative Commons Attribution-NonCommercial-NoDerivatives 4.0 International License.

https://doi.org/10.1515/9783110599572-011 
vitam excoluere per artis (Aen. 6.663). Audano follows this phrase all the way down to the (non-hexametrical) motto on Nobel prize medals in medicine, sciences, and literature: inventas vitam iuvat excoluisse per artas. The second regards patriotism and the desire for glory: vincet amor patriae laudumque inmensa cupido (Aen. 6.823). Audano's study shows, among other things, the continuing influence and adaptation of Vergilian thought, as well as the elements of the Roman and classical traditions Vergil's thought conveys.

Can we undertake the sort of reading Audano performs with phrases less celebrated than those that appear on Nobel prize medals, where the imitation is more subtle? Can we do it on a still larger scale, ensuring that we capture (nearly) every instance, in a way that illuminates each of the contexts in which it appears? This article will argue "yes" here as well.

To demonstrate how we can readily find the recurrence of echoing phrases over many texts, this article will show how a suite of digital methods were employed that make such detection possible. Information about these methods can enable scholars who want to carry out such investigations, or at least provide a starting point for the discussion of best practices.

To demonstrate that this way of studying intertextuality can be enlightening, this article offers the case study of one echoing phrase, emanating again from the Aeneid. Here we will see a familiar type of influence, where subsequent poets are plainly borrowing from Vergil with nods to and variations on their predecessor. We will also consider the raw poetic materials from which Vergil forged his phrase. And we will discover instances where the phrase seems to pass beyond the realm of poetic imitation, or even generic language, to become a constellation of ideas and images that float free into the thought-world drawn on by later poets and even prose authors. In these last cases, the conceptual cluster remains distinctive, but the link to the Aeneid fades all but entirely.

Considering this wide swath of textual relationships together brings us to a model of intertextuality different from the common one mentioned above. It is a conception that does not always privilege the source text as generative of meaning, since the language at times breaks free from the source. What remains distinctive are some of the essential components of the phrase that, in this case, a canonical author forged, but carry on living, as it were, beyond a discernible relationship with that author's text, to become what we might call a viral phrase. ${ }^{5}$

5 In referring to these phrases as "viral" and in my section titles I use a biological metaphor to express the apparent vitality and adaptability of bits of language that persist. For a deeper exploration of the analogies and overlaps between biology, bioinformatics, and classical literature see Chaudhuri and Dexter (2017). 


\section{The successful genotype: Aeneid 12.67-69}

In the closing book of Vergil's Aeneid, facing the defeat of the Latin forces at the hands of Aeneas and his Trojans, Turnus proposes to meet Aeneas in single combat to decide the conflict. Turnus's potential mother-in-law Amata bemoans his plan, implying that Turnus might lose by saying that she does not want to see Aeneas as her son-in-law. Standing nearby, Turnus's intended bride, Lavinia, blushes:

Indum sanguineo veluti violaverit ostro

siquis ebur, aut mixta rubent ubi lilia multa

alba rosa, talis virgo dabat ore colores.

Aeneid 12.67-69

As when someone stains Indian ivory with crimson dye, or white lilies blush when

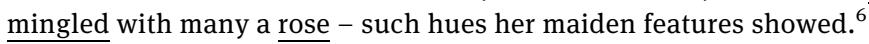

Just what this blush means has been much debated. Lavinia could be a modest maiden blushing at the thought of marriage, especially to an enemy of her supposed betrothed. She could feel self-conscious because Turnus gazed at her, she believes she is causing strife, or she is in love with Turnus. ${ }^{7}$ My focus in this article will not be on these causes, but rather on the imagery Vergil employs to describe Lavinia's blush, in particular the white and red flowers. ${ }^{8}$

This passage came to my attention through an exploratory search comparing Vergil's Aeneid and Prudentius' Psychomachy using the Tesserae multi-text tool. Tesserae provides a website that allows for various forms of intertextual search in Greek, Latin, and English. ${ }^{9}$ The multi-text tool allows users to find similar phrases in two works, and then find other locations in a selected corpus where the common language from the first two texts also occurs. My search found that this passage of the Aeneid resembled one in the Psychomachy, as well as numerous others. To complement the Tesserae findings, I also searched the Packard Humanities Institute Latin corpus for similar words, employed the "Cited Loci of the Aeneid" tool published by Matteo Romanello, searched

6 Fairclough and Goold (2000) Loeb translation. All subsequent translations are from the Loeb series unless otherwise noted.

7 See Tarrant $(2012,105)$ ad 12.64-69.

8 There is a large and overlapping poetic tradition of contrasting the colors white and red (see references at Cairns (2005, 211 n. 33)). This piece will focus more closely on images with Vergil's two flowers.

9 For an overview of Tesserae and the related tools Fìlum, Musisque Deoque, and TRACER, see Coffee (2018). 
Google Books, and consulted the 2012 commentary on Aeneid 12 by Richard Tarrant. ${ }^{10}$ In the readings below, I will indicate in the notes where I found each parallel in order to demonstrate how search methods can be combined to develop readings of viral intertexts.

\section{DNA fragments: Ennius and Propertius}

In Latin literature prior to Vergil, we find disparate elements of his Lavinia image. Ennius had compared a blush (whose we don't know) to milk mixed with purple dye. ${ }^{11}$

et simul erubuit ceu lacte et purpura mixta.

Annales $\overline{361 \mathrm{Sk}}$.

And she blushed then like milk and crimson mingled. ${ }^{12}$

As in this case, sources prior to Vergil contrast the colors white and red, but do not connect lilies and roses with blushing. ${ }^{13}$ This seems to be true of Greek literature as well. The two most common Greek words for lily (кpivov) and rose (’́óoov) appear together in only three passages prior to Ennius, two from Herodotus and one from Aristophanes. None of them describe love, blushing, or a maiden, but give the two flowers as undistinguished members of longer lists. ${ }^{14}$

Vergil therefore seems to have acted under his own inspiration when he took Ennius's description of a blush as contrasting red and white and rendered it as white lilies reflecting the red glow of roses. The flowers of course brought their

10 PHI: http://latin.packhum.org/browse: last access 2019.01.31. Cited Loci of the Aeneid: http://aeneid.citedloci.org: last access 2019.01.31. Google Books: https://books.google.com: last access 2019.01.31. Tarrant (2012, 106-107) ad 12.67-69. Tarrant naturally does not list all these parallels in his printed commentary: "citation of parallel passages [...] is confined to those that seemed most relevant or illuminating” (44).

11 Parallel noted by Tarrant (2012).

12 Translation adapted from Warmington (1988, frag. 352). Skutsch $(1985,526)$ ad Enn. Ann. 361 notes the Aeneid parallel.

13 As observed by Tarrant, who also notes another potential strand of influence. The Greek novelist Achilles Tatius describes a woman's reddened white cheek, alludes to the Homeric passage upon which the first part of Vergil's simile is based (Iliad 4.141-147), and then mentions roses (Leucippe and Clitophon 1.4.3). Cairns (2005, 204-205) suggests that the common elements in Vergil and Achilles Tatius stem from the Acontius and Cydippe episode of Callimachus's Aetia.

14 Herodotus's Histories 1.195.2, 2.92.4. Aristophanes Clouds 910-911. Passages found through a search for kpív- and póo- in the Thesaurus Linguae Graecae. 
own associations. Flowers had been used as an image to portray women's complexions, if not blushes. Catullus had described a bride as shining like a white chamomile or yellow poppy. ${ }^{15}$ Lilies were associated with short lives: Horace, while drinking with his friends, muses on the breve lilium (Carm. 1.36.16). ${ }^{16}$

Vergil provides his own precedents for his use of lilies. In their two other appearances in the Aeneid, lilies are associated with death and passion. Other than in book 12, lilies appear only in the underworld in book 6. The souls on the banks of the Lethe are compared to bees on shining lilies (6.709). Then Anchises wishes to scatter lilies on the grave of Marcellus, though these lilies are purple (6.882-884). Elsewhere in Vergil's works, lilies are associated with love (Bucolics 2.45; 10.26, on Silvanus, approaching the forlorn Gallus) and prosperous farming (the Cilician farmer in Tarentum of Georgics 4.131). ${ }^{17}$ The lilies used to describe Lavinia's blush might therefore bring connotations of fatality from the underworld that are appropriate for the fortunes of Turnus and the Latins, and, more distantly, erotic connotations from the Bucolics.

Vergil's other flower, the rose, is associated with youth, and with youthful love and death. ${ }^{18}$ Philostratus writes that the rose is the garland of youth, a sentiment previously voiced by Anacreon, but, as Philostratus continues, neither love nor the rose last long. ${ }^{19}$

Another poet writing prior to Vergil does bring together lilies and reddish flowers in phrasing similar to Vergil's, though not in the context of blushing. Of Propertius's four books of elegies, the first seems to have been published around the year $30 \mathrm{BCE}$, eleven years before the publication of the Aeneid at Vergil's death in 19 BCE, and before Vergil had even completed his Georgics, in 29 BCE. $^{20}$ It seems likely then that Propertius composed the following passage of Elegies 1 before Vergil crafted the Lavinia description in the Aeneid. ${ }^{21}$

15 Catullus 61.185-188. Catullus's word for the white flower is parthenice, the meaning of which is not entirely clear. "Chamomile" is the suggestion offered by Quinn $(1973,274)$ ad 61.187 .

16 Compare also Valerius Flaccus, lilia per vernos lucent velut alba colores / praecipue, quis vita brevis totusque panumper / florent honor fuscis et iam Notus imminet alis (6. 492-494). This and the words of Horace are cited by Allen $(1956,108)$.

17 (Tarrant 2012, 108) ad 12.68.

18 This paragraph is adapted from Allen $(1956,108)$.

19 Philostratus 55.34, Anacreon 44.9-11. On the brevity of life associated with roses, Allen gives further references to Horace Odes 2.3.13-14 and for Ausonius, Peiper (1886, 411).

20 Camps $(1961,5-7)$ puts the dates of the four books of elegies in order as 30, 26, 23, and 16 BCE.

21 Propertius passages from Books 1 and 3 discovered through the Tesserae search. 
hic erat Arganthi Pege sub vertice montis, grata domus Nymphis umida Thyniasin, quam supra nulli pendebant debita curae roscida desertis poma sub arboribus, et circum irriguo surgebant lilia prato candida purpureis mixta papaveribus.

Elegies 1.20.33-38

Here beneath the peak of the mountain Arganthus lay the well of Pege, the watery haunt so dear to Bithynia's nymphs, over which from lovely trees there hung dewy apples that owed nothing to the hand of man, and round about in a water-meadow sprang snowy $\underline{\text { lilies mingled with purple poppies. }}{ }^{22}$

Propertius is describing the pond where Hylas will be abducted by the nymphs. He mentions white lilies and reddish flowers (here purple/red poppies) in an erotic context of loss (of Hylas by Hercules). He uses the word mixta that Vergil will later use and an equivalent for Vergil's alba - candida. The main differences are the absence of roses and blushing.

Propertius includes the roses, at least, in a poem in Book 2 of his Elegies. ${ }^{23}$

nec me tam facies, quamvis sit candida, cepit

(lilia non domina sint magis alba mea;

ut Maeotica nix minio si certet Hibero,

utque rosae puro lacte natant folia).

Elegies 2.3.9-12

Lilies would not surpass my mistress for whiteness; 'tis as though Maeotic snows were to strive with Spanish vermilion, or rose leaves floated amid stainless milk.

Book 2 was published around 25 BCE, six years before the posthumous publication of the Aeneid in 19 BCE, so Propertius could not have known the final form of Vergil's epic. Yet he goes on in Book 2 to show his awareness of the Aeneid, famously predicting that "something greater than the Iliad was being born." 24 We cannot say for certain, then, if Propertius knew the Aeneid 12 scene with Lavinia or, if so, in what form. What we can say is that his arrangement of floral imagery, though highly similar, does not have the elements and structure that many others would later imitate in Vergil. Propertius describes not the blush of his mistress, but only her complexion. He uses both flowers, but does not

22 Translations of Propertius adapted from Butler (1912).

23 Parallel between Elegies 2.3.9-12 taken from Enk $(1962,58)$ on Propertius Elegies 2.3.11-12.

24 nescio quid maius nascitur Iliade, 2.34.66. 
combine them directly, instead picturing rose leaves floating in milk, borrowing the milk, it would seem, from Ennius.

To summarize the genesis of Vergil's floral metaphor for Lavinia's blush, then, we might say, with some simplification, that he took from Ennius the contrast between red and white to describe a blush and combined it with the contrast between red and white flowers from Propertius. Depending upon the order of influence, he may also have borrowed the rose from Propertius's Book 2.

By substituting lilies and roses to describe a blush for Ennius's milk and dye, Vergil fashioned a more compelling image. Not only does he capture the mingling of the colors, as Ennius had. In their beauty and fragility, the flowers convey the beauty and fragility of the maiden Lavinia. They also carry connotations of eroticism and mortality appropriate to a war over, among other things, a bride.

\title{
The first (non-) variation: Propertius
}

Book 3 of the Elegies appeared some four years prior to the full publication of the Aeneid. In this context, it is interesting to note that his mention of mixed flowers in Elegies 3 is diffuse in comparison with Elegies 1 and 2.

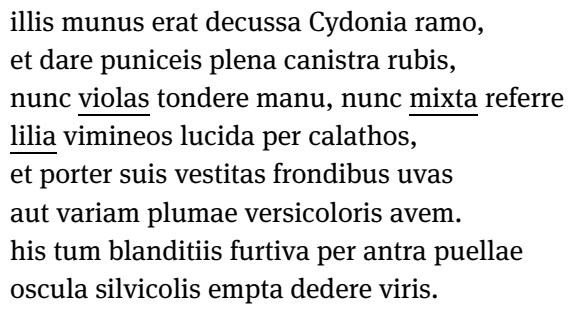

Elegies 3.13.27-32

\begin{abstract}
Their offerings were Cydonian apples shaken from the bough; they gave baskets filled with purple brambles, now with their hands plucked violets, now brought home shining lilies mingled together in the maidens' paniers, and carried grapes clad in their own leaves or some dappled bird of rainbow plumage. Bought by such wooing were the kisses that girls gave their sylvan lovers in secret caves.
\end{abstract}

Here again we find, within an erotic context (wooing maidens in the Golden Age), mixta lilies that are (shining, lucida, therefore) white. Yet still there is no blush, the flowers joined with lilies are violets rather than roses, and there is no reflection, as in the description of Lavinia, of a surrounding context of blood (sanguineo) and loss. If Propertius was aware of Vergil's Lavinia passage, he does nothing to show it here, but seems to be just varying his own descriptions from Elegies 1 and 2. 


\title{
Minor to major mutations I: Ovid
}

The complex potency of Vergil's image - a combination of beauty, eroticism, honor, shame, blood, and loss, conveyed at a critical moment within an instantly classic poem - made it irresistible to his successors. Subsequent authors at times created minor mutations, varying Vergil's language only slightly, inviting recollection of the Aeneid. They also created major mutations, where elements of Vergil's image remain, but the language is considerably more diffuse, to the point of obscuring any connection with the Augustan epic.

Ovid provides the earliest minor variation in his first set of published poems, the Amores. ${ }^{25}$

\author{
at illi \\ conscia purpureus venit in ora pudor, \\ quale coloratum Tithoni coniuge caelum \\ subrubet, aut sponso visa puella novo; \\ quale rosae fulgent inter sua lilia mixtae, \\ aut ubi cantatis Luna laborat equis, \\ aut quod, ne longis flavescere possit ab annis, \\ Maeonis Assyrium femina tinxit ebur. \\ hic erat aut alicui color ille simillimus horum, \\ et numquam visu pulchrior illa fuit.
}

Amores 2.5.35-42

But she - her guilty face mantled with ruddy shame, like the sky grown red with the tint of Tithonus's bride, or maid gazed on by her newly betrothed; like roses gleaming among the lilies where they mingle, or the moon in labor with enchanted steeds, or Assyrian ivory Maeonia's daughter tinctures to keep long years from yellowing it. Like one of these, or very like, was the color she displayed, and she was never fairer to look upon. ${ }^{26}$

Ovid is being characteristically subversive, taking Vergil's illustration of a chaste royal maiden's blush during a crucial council scene to describe his girlfriend's blush when he walks in on her cheating on him with another man. To achieve his humorous bathos, Ovid's passage must recall the Aeneid. He duly includes nearly every element of Vergil's floral image including the blush. He also includes the notion of dyeing from other half of Vergil's comparison. ${ }^{27}$ To make the connection clearer still, Ovid includes the words sponso [...] novo, recalling the problem of Aeneas (or Turnus, if you like) as "new husband" for Lavinia.

25 Parallel discovered by the Tesserae search and noted by Boyd (1997, 113-114) and Tarrant (2012).

26 Showerman and Goold (1977) translation.

27 Which, again, Vergil drew from the description of a wounded Menelaus at Iliad 4.141-147. 
In a subsequent work, his Ars Amatoria, Ovid switches to a Major Mutation. Using some of the same distinctive vocabulary, he simply revisits the topos of flowers as short-lived, applying it to the transience of beauty. ${ }^{28}$

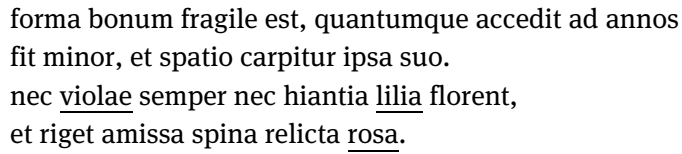

Ars Amatoria 2.113-116

\begin{abstract}
A frail advantage is beauty, that grows less as time draws on, and is devoured by its own years. Violets do not bloom forever, no lilies open-mouthed; when the rose is perished, the hard thorn is left behind. ${ }^{29}$
\end{abstract}

In contrast to the Amores passage, there is no blush, no whiteness to the lilies, a different placement of rosa, and an additional flower, violae. Yet the core DNA of Vergil's image remains: roses, lilies, and their association with loss. It seems less likely that Ovid is intentionally alluding to Aeneid 12.67-69 here than was the case in the Amores. Instead, it seems that the constellation of images and ideas has passed over into becoming poetic material that, while remaining distinctive, is a malleable formation that can be employed for other purposes even outside the genre of epic.

Ovid gives the material a final reworking in his Metamorphoses, in a eulogy for the centaur Cyllarus during the battle with the Lapiths. Ovid tells us that Hylonome, beloved of Cyllarus, used to adorn herself with rosemary, violets, roses, lilies.

haec et blanditiis et amando et amare fatendo

Cyllaron una tenet; cultus quoque, quantus in illis

esse potest membris, ut sit coma pectine levis,

ut modo rore maris, modo se violave rosave

inplicet, interdum candentia lilia gestet.

Metamorphoses 12.408-411

She, by her coaxing ways, by loving and confessing love, alone possessed Cyllarus; and by her toilet, too, so far as such a thing was possible to such a form; for now she smoothed her long locks with a comb, now twined rosemary, now violets or roses in her hair, and sometimes she wore white lilies. ${ }^{30}$

28 Parallel found by the Tesserae search.

29 Mozley (1939) translation.

30 Miller and Gould (1984) translation. 
Again in a context of loss, Ovid seems to be picking up his own formulation from the Ars Amatoria - he keeps the violets he added there and now further includes rosemary - but retains an additional Vergilian element by describing the lilies as "white" (candentia). Ovid's use again seems less a conscious allusion than a craftsman's repurposing of elements at the edge of the common stock of language.

\section{Jumping species: Seneca's Epistles}

The next possible echo is arguably the least connected to Vergil and so conversely the most interesting test case. It is the least connected in part because it is our only instance of a potential similarity with the Aeneid imagery in prose. It comes from Seneca's Epistles, when the philosopher is discussing the problems of luxury and decay. ${ }^{31}$ Seneca objects that the ultra-wealthy of Rome work out elaborate tricks to grow roses and lilies in the winter, rather than waiting for them to grow naturally in the spring. He calls this practice contra naturam, a damning condemnation from a Stoic, signifying a practice both unnatural and morally wrong.

non vivunt contra naturam qui hieme concupiscunt rosam fomentoque aquarum calentium et calorum apta mutatione bruma lilium, florem vernum, exprimunt?

Epistles 122.8

Do not people live contrary to Nature who crave roses in winter, or seek to raise a spring flower like the lily by means of hot-water heaters and artificial changes in temperature ${ }^{32}$

At first sight, it strains belief that Seneca's condemnation of luxurious living has anything to do with Vergil's Lavinia description. He may mention the canonical botanical pairing, but the context seems entirely different. Not only is there no love, desire, or marriage. This is not even a poetic narrative, but a philosophical prose diatribe against decadence. Yet it is precisely the note of decadence, added to the mention of flowers, that this passage does share with the Aeneid. Roses, lilies, and loss were the core features of the image we identified in Ovid. All are here as well. For Seneca, the loss lies in the wasteful cultivating of flowers out of season and the decline of morality that leads to such extravagance.

31 Parallel found by the Tesserae search.

32 Gummere (1925) translation. 
In all likelihood, so far from trying to reference the Aeneid, Seneca was not even thinking about the poem in composing this passage. Of course, Seneca was deeply conversant with the Roman poetic tradition and gladly reused elements of Augustan poetry, notably in his tragedies. In this case, that familiarity seems to have resulted in the unconscious employment of a template Vergil constructed, loosely presented in prose and in another thematic context. Vergil's poetic image has, as it were, jumped species from poetry, appearing now in literary prose.

\section{Minor and major variations II: Statius's Silvae}

In his Silvae, the Flavian poet Statius follows the same progression from allusion to conceptual reuse as Ovid, offering first a Minor and then a Major variation. The Minor Variation is found in Silvae 1.2, a wedding poem (epithalamion) in honor of Statius's patron Stella and his bride Violentilla. ${ }^{33}$

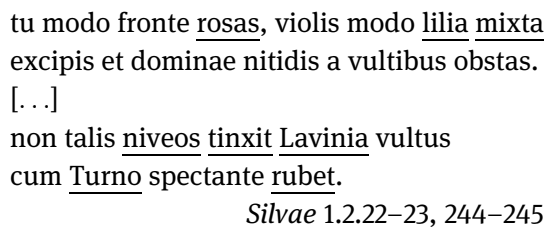

On your brow you receive now roses, now lilies mingled with violets, shielding your mistress's shining face.

[...]

Not so did Lavinia tinge her snow-white cheeks, blushing before Turnus's gaze. ${ }^{34}$

In this instance, Statius makes the connection with the Aeneid even more explicit than Ovid did in the Amores. Statius had already mentioned Aeneas's mother Venus at opening of poem (genetrix Aeneia, 11) among the goddesses who come to attend the wedding. Then at lines 22-23 he uses Vergil's exact words lilia and mixta, with the first in the same line position where it appeared in the Aeneid, and he slightly alters Vergil's rosa to rosas. In a parallel to Vergil's mention of the "white" (alba) rose, Statius just before these lines

33 Statius parallels found by the Tesserae search.

34 All Statius translations from Shackleton Bailey (2004). 
mentions the "snowy limbs" (niveos [...] artus, 20) of the bride. ${ }^{35}$ If the poetic debt were not clear enough, later in the poem Statius contrasts Violentilla explicitly with Lavinia blushing under the gaze of Turnus (244-245).

Statius nevertheless creatively reorients Vergil's imagery. Rather than describe the blush of the bride Violentilla, lilies and roses are woven into the garland worn by the bridegroom, Stella. Rather than present Violentilla as blushing red like Lavinia, Statius only refers to her as fair-skinned.

Why this reshuffling, apart from mere variation? While nodding to Vergil, Statius omits one core component of his predecessor's image, the notion of loss. This is because, in this celebratory poem, Statius must avoid summoning the shadow that hangs over Lavinia. He instead deploys Vergil's flowers to convey youth, beauty, and possibly fragility, all in a hopeful direction. Hence his dissociation of Violentilla from Lavinia's blush and the flowers. Unlike Lavinia, Violentilla is caught in no shameful or harrowing situation, but celebrates a joyful occasion. Although Statius must alter elements of Vergil's image, if he is to create a contrast between Violentilla and Lavinia, he must still evoke the image clearly. Hence his direct verbal reminiscences and explicit mention of Lavinia and Turnus.

In his second use of Vergil's image, Statius takes the exact opposite tack. His poem 3.3 is a consolation to his patron Claudius Etruscus for the death of his father. In the poem, Statius touches on the death of Etruscus's mother when Etruscus was still a very young child, and describes her passing in familiar terms.
sed media cecidere abrupta iuventa
gaudia florentesque manu scidit Atropos annos, qualia pallentes declinant lilia culmos
pubentesque rosae primos moriuntur ad austros, aut ubi venia novis exspirat purpura pratis.
Silvae 3.3.126-130

But your joys fell earthwards, broken off in mid youth, and Atropos's hand severed your blooming years, as lilies droop their paling stems and roses die at the first sirocco or as when vernal purple expires in fresh meadows.

The verbal reminiscences here are limited to the mention of lilies and roses, with no supplementary words regarding mixing or whiteness, nor mention of Aeneid characters. The context of marriage and desire is also absent. What

35 The manuscript also has niveis in place of the nitidis printed here, another possible parallel, but I follow the Loeb of Shackleton Bailey (2004), who finds niveis after niveos just above implausible and so emends to nitidis. 
remains again is the core conceptual cluster: lilies, roses, and the concept of loss. The death of a young mother is compared to flowers drooping in the heat of summer. As in Ovid's second two uses of Vergil's image, this hardly seems an instance of allusion, but rather the reappearance of the conceptual complex. Like Ovid, once he had used Vergil's image explicitly, Statius seems to have absorbed it and redeployed its core, perhaps unconsciously, out of a feeling for its existing resonances. ${ }^{36}$

\section{Crossing the language barrier? Heliodorus's Aethiopica}

As Vergil's image spread, it eventually crossed from Latin into other languages, including eventually, as we will see, 17th-century English poetry. Much closer to Vergil's day, we find a possible effect of his image in the work of a Greek novelist, Heliodorus, who seems to have published his Aethiopica sometime around 230 CE. ${ }^{37}$ Any use Heliodorus makes of Vergil's Lavinia metaphor is necessarily a Major Mutation, since it is rendered in Greek.

The Aethiopica tells the story of two young lovers, Theagenes and Chariclea, and the long series of tribulations they suffered in Greece, Egypt, and Ethiopia before their eventual marriage. According to Tarrant, who himself cites Ewen Bowie, there are two passages in the Aethiopica that "interweave [...] V[ergil]'s simile with its main Iliadic model." ${ }^{38}$ The first is a description of the beauty of Theagenes, despite his having been wounded.

36 Statius's contemporary Martial employs the motif as well. Martial writes of a new bride named Cleopatra, who flees from her over-eager husband to a pool: lucebat, totis cum tegeretur aquis: condita sic puro numerantur lilia vitro, sic prohibet tenuis gemma latere rosas, Epigrams 4.22.4-6 ("Brightly she showed, though covered by the o'erlapping water. So, shut in pellucid glass, lilies may be counted, so crystal forbids tender roses to lurk hidden.” (Ker 1968) Loeb translation.). Here again we find the associations of eroticism, innocence (fleeing the marriage bed), purity (new bride, water), and violation. Herrick picks up Martial's image in his "Lily in a Crystal": "You have beheld the smiling rose / When virgins' hands have drawn / O'er it a cobweb-lawn / And here you see this lily shows, / Tomb'd in a crystal stone, / More fair in this transparent case / Than when it grew alone / And had but single grace" (I owe the Herrick reference to Prof. A.E.B. Coldiron.)

37 See Oxford Classical Dictionary vol. 4 under "Heliodorus," 654.

38 Tarrant (2012) ad Aen. 12.67-69, 107. The Iliad 4 parallel with Menelaus noted above seems to be in play as well. 


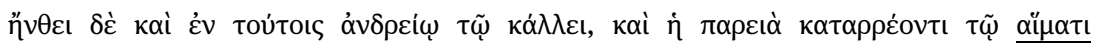

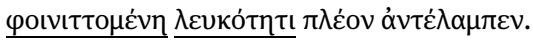

Even in this wounded condition he bloomed with a manly beauty, and his cheek, growing crimson from the blood flowing down it, gleamed by contrast with a greater whiteness. ${ }^{39}$

Aethiopica 1.2.3

Here we have the contrast between red and white, representing blood and white skin of a lover with thoughts of marriage, and also the sense of possible loss through death, though Theagenes is not in fact killed. Yet loss is the only one of the canonical core elements Vergil's image to appear. There is no mention of flowers, much less lilies, roses, or their mixture.

The second passage mentioned by Tarrant describes the reaction of the nephew of the Ethiopian king Hydaspes to the king's decision to marry him to Chariclea.

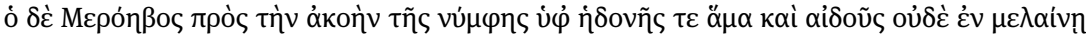

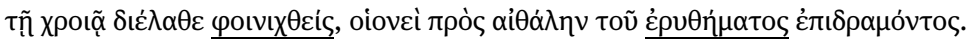

At the mention of the 'bride' Meroebos, at once from pleasure and embarrassment, went visibly crimson even with his black skin, the blush running over his face like a flame running over ash.

Aethiopica 10.24.2

Here again, we have elements of Vergil's image, in this case including an actual blush and red skin. Lacking still is any mention of flowers, or, in this case, even of loss.

Of all of the instances considered so far, these seem least indebted to Vergil's Lavinia image, rather than just to Homer or generic descriptions of bleeding or blushing. If nothing else, however, the judgment of Tarrant and Bowie that there was a genetic line from Vergil to Heliodorus makes these passages worth keeping under consideration.

\section{Missing genomes: Claudian's De raptu Proserpinae}

Back in the world of Roman poetry, Claudian, a poet of the late 4th and early 5th centuries CE, makes much more explicit use of Vergil's image, but

39 Translations of Heliodorus from Tarrant $(2012,107)$ ad Aen. 12.67-69. 
nevertheless leaves a curious gap. In his poem on the rape of Persephone, Claudian describes how Zeus gives Venus the task of luring the divine maiden out into the fields so Pluto can abduct her. Persephone is alone at home weaving when Venus appears, along with Pallas and Diana, and the maiden blushes at the sight of the goddesses. ${ }^{40}$

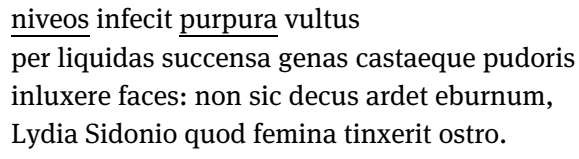

A glowing blush that mantled to her clear cheeks suffused her fair countenance and lit the torches of stainless purity. Not so beautiful even the glow of ivory which a Lydian maid has stained with Sidon's scarlet dye. ${ }^{41}$

Claudian draws from Vergil, and Homer before him (Il. 4.141-147), for his mention of ivory (decus [...] eburnum for Vergil's ebur) and dye (ostro). He adds a woman performing the dyeing, an element borrowed either from Ovid's Amores passage or the original Homeric context. We also have a blush, here that of Persephone. And there is a looming sense of loss from the imminent rape and abduction of Persephone comparable to the cloud of uncertainty hanging over Lavinia. Absent, however, is any mention of lilies and roses; Claudian brings together nearly every element but the canonical flowers. Why?

It is possible that, with the appearance of numerous versions of Vergil's image in the intervening centuries, Claudian felt the roses and lilies motif could only be refreshed with a major variation, in this case omitting the flowers. He may simply have preferred the dyeing metaphor to the floral one. Or he may have wanted to preserve the effect of flower imagery for the scene of Persephone's abduction. In that scene, the fields are bright with flowers as Persephone and the other goddess race to gather them (2.88-150). And we do indeed find lilies and roses there (lilia [...] rosis, 2.128-130), though in a landscape also filled with violets, marjoram, privet, and hyacinth. Despite the missing flowers, the elements Claudian employs in his description of Persephone's blush sufficed to make his image vivid and signal his awareness of the tradition.

40 This passage is noted by Skutsch $(1985,526)$ ad Enn. Ann. 361 and Tarrant $(2012,107)$ ad Aen. 12.67-69.

41 Platnauer (1922) translation. 


\section{Blending species: Prudentius's Psychomachy}

Around the same time Claudian was writing De raptu Proserpinae, the Christian poet Prudentius created his Psychomachy, a poem in hexameters describing the clash between virtues and vices within the soul. These battles consume the bulk of his 915-line poem, but once the various virtues defeat their vicious counterparts, they work together to build a temple that Christ can visit when he visits to earth. Ruling in that temple is Wisdom (Sapientia), who presides over humanity and creates laws to keep it safe. In ten lines toward the end of the poem, Prudentius describes the scepter Wisdom holds. ${ }^{42}$

in manibus dominae [Sapientiae] sceptrum non arte politum

sed ligno vivum viridi est, quod stirpe reciso,

quamuis nullus alat terreni caespitis umor,

fronde tamen viret incolumi, tum sanguine tinctis

intertexta rosis candentia lilia miscet

nescia marcenti florem submittere collo.

huius forma fuit sceptri gestamen Aaron

floriferum, sicco quod germina cortice trudens

explicuit tenerum spe pubescente decorem

inque novos subito tumuit virga arida fetus.

reddimus aeternas, indulgentissime doctor,

grates, Christe, tibi, meritosque sacramus honores

ore pio; nam cor vitiorum stercore sordet.

Prudentius, Psychomachy $879-890$

In the hands of the sovereign [Wisdom] is a scepter, not finished with craftsman's skill but a living rod of green wood; severed from its stock, it draws no nurture from moist earthly soil, yet puts forth perfect foliage and with blooms of blood-red roses intermingles white lilies that never droop on withering stem. This is the sceptre that was prefigured by the flowering rod that Aaron carried, which, pushing buds out of its dry bark, unfolded a tender grace with burgeoning hope, and the parched twig suddenly swelled into new fruits. We give to Thee, O Christ, Thou tenderest of teachers, unending thanks and offer to Thee the honour that is thy due with loyal lips - for our heart is foul with the filth of $\sin .{ }^{43}$

Prudentius's word intertexta tempts the modern reader as a possible hint at his borrowings, but we hardly need the invitation, since the Christian poet uses words nearly identical to Vergil's to describe mixed roses and white lilies as well as blood. Prudentius draws further attention to his intertextuality - or, rather, biblical precedent - by simply telling us that Wisdom's flowering

42 Parallel found by the Tesserae search.

43 Thompson (1949) translation. 
scepter was prefigured by the staff of Aaron, signifying burgeoning hope, a reference to Numbers 17.8. For the classical reader, the blooming scepter also recalls the scene in the Iliad when Achilles swore he would not fight for the Achaeans until the scepter he was holding came alive and began to grow new shoots (Il. 1.234-239).

The new Christian context gives Prudentius the opportunity to take the canonical image in a wholly new direction. As part of his program of repurposing classical conceptions and classical hexameter poetry to convey the messages of Christianity, Prudentius reverses the associations of loss in Vergil's image to make roses and lilies a sign of resurgence. The sprouting flowers illustrate the establishment and perpetual vigor of the reign of Wisdom and the virtues under the eye of Christ on earth. More broadly, they allude to the resurrection of Christ, the rebirth he offers to his followers, and, especially for Prudentius the poet, the rebirth of elements of classical culture into the new Christian tradition.

Prudentius's project of poetic conversion extends to the details of the image he lays claim to. In the Aeneid, beyond describing a blush, the red and white of the roses and lilies connotes the innocence of Lavinia, the blood of her blush, and, combined with the word "blood-colored" (sanguineo), the past and future bloodshed caused by her suitors. For Prudentius, the roses and lilies also evoke the innocence and blood - those of Christ, as two central elements of his story. Prudentius in fact uses the word "blood" (sanguine) just before his mention of the flowers, and just after the description of Wisdom concludes his poem with praise of Christ, beginning with lines 888-890 quoted here. Vergil's flowers are used not just to convey the loss of innocence and blood, but their redemption. ${ }^{44}$

\section{An isolated atavistic strain: Anonymous}

In his Ars Grammatica, the 4th-century CE grammarian Martius Victorinus, quotes the following unattributed line as an example of the formation of the pentameter:

44 Martha Malamud points out to me a further, intratextual reversal as well. Earlier in the poem, the vice Luxuria leaves a banquet for war with the Virtues, stepping on flowers (ebria calcatis ad bellum floribus ibat, 320, "trampling on the flowers, she was making her drunken way to the war,” Thomson (1949) trans., adapted) and then attacks the Virtues with violets and rose petals (uiolas lasciua iacit foliisque rosarum / dimicat et calathos inimica per agmina fundit, 326-327, "she throws violets and fights with rose-leaves, scattering baskets of flowers over her adversaries."). The appearance of roses and lilies on the staff of Wisdom therefore also reclaims for Christianity flora previously associated in the Psychomachy with decadence. 


\section{[...] lactea sanguineis lilia mixta rosis. $^{45}$ \\ [.. .] milk-white lilies mixed with blood-red roses.}

Unfortunately, lacking the author and the rest of the poem, we know nothing about the context of the fragment, including whether it involved love or loss. What we can say is that the author was clearly attempting to out-Vergil Vergil. The poet packed as many of the by-then-canonical words into one line as possible. Vergil put his roses and lilies on different lines. In the Amores, Ovid put the flowers on the same line, together with the word mixta, but didn't use Vergil's word for "bloody" or his concept of whiteness. In a tour-de-force distillation, our poet manages to fit "lilies," "roses," "mixed," "milky-white," and "bloodred" all into one line, even giving up one hexameter foot to jam them into a pentameter. In so doing, the poet stylishly mints a hyper-canonical version of Vergil's own canonical image.

\section{Autochthonous blooms among the Church Fathers}

At this point, it might be useful to consider an example that seems, as much as possible, unrelated to Vergil's image while still containing some of its elements, so that we can get a sense of where the boundary of connection might lie. The church father John Chrysostom, writing in Greek, shows a fondness for the pairing of roses and lilies. In describing a reading from the New Testament, Chrysostom says it seems to him like a great variety of flowers, roses, violets, and

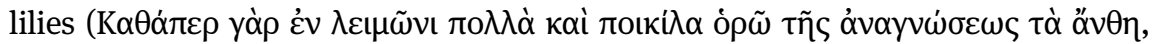

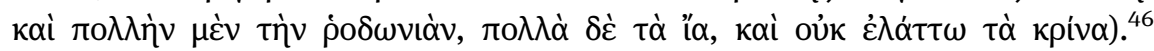
Likewise, in writing in praise of the martyr St. Ignatius, Chrysostom says that it is hard to know where to begin in praising the great and manifold works of the saint, because it is as if we were in a meadow, seeing roses, violets, lilies, and

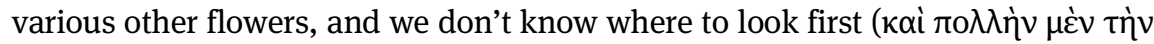

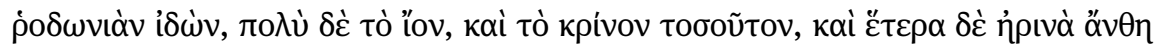

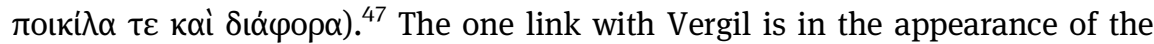
two canonical flowers. Beyond that, even apart from the different language, there is no discernible verbal or thematic similarity. At most, there is the remote

45 (Keil 1961, 105 Vol. 6). This line was found with a PHI search for "ros" near "lili."

46 Scr. Eccl. Ad populum Antiochenum, Migne (1857) Vol. 49, 17 lines 22-23.

47 Scr. Eccl. In sanctum Ignatium martyrem, Migne (1857) Vol. 50, 587, line 46-48. 
possibility that Vergil's influence is felt just in mention of the two flowers together. If so, it is the diminution of a wave at one end of the sea into one of countless ripples at the other end.

\section{Medieval mutation: Carmina Burana}

Among the vast corpus of medieval Latin, we find an echo indebted to Statius's optimistic version of the trope. Within the Carmina Burana collection, a short poem recalls the Pervergilium Veneris in its celebration of the springtime renewal of nature and stirring of erotic passion. The poem contains the lines:

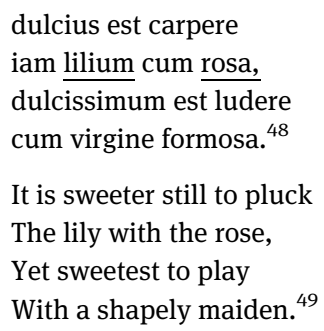

The lily and the rose are paired as an expression of untroubled joy connected with nature and erotic delights, with no trace of a blush, much less overtones of loss. This author has essentially crossed Vergil's image with the natural wonder and vigor expressed not only in the Pervigilium Veneris but also in the opening of Lucretius's De rerum natura.

\section{Renaissance rebirth: Vida's Christiad}

From this free, medieval adaptation of the erotic strain in Vergil's image, it is not surprising that a Renaissance poet would return quite deliberately ad fontes. In his Christiad, published in 1535, Marcus Hieronymus Vida produced an epic poem in six books narrating the passion of Christ. In his Christian answer to the great Roman epic, Vida borrowed substantially from the Aeneid. ${ }^{50}$

48 (Schmeller 1847, 181). I came upon this passage in Allen (1956, 93-111), which I discovered through a JSTOR search for "rose" and "lil."

49 My translation.

50 Di Cesare $(1964,114)$ writes that "the style [of the poem] seems almost cento," though he also notes (145) that "there is no example in the entire Christiad of a line, or even a half-line, lifted bodily out of the Aeneid." 
In his epic, Vida uses Vergil's description of Lavinia daringly to portray the blush of none other than the Virgin Mary. Joseph, pleading with Pilate to spare Christ, tells the story of Christ's origins, including how he himself was once a suitor to Mary, who blushed before him and the other assembled suitors: pudor ora pererrans / cana rosis veluti miscebat lilia rubris (3.179-180, "a blush flashed across her pale face like red roses among lilies"). ${ }^{51}$ As with Prudentius, there is no immediate connotation of loss or violence, though the story is told by Joseph, who will fail in his efforts to keep Christ from torture and crucifixion. But Vida's language and the context of proposed marriage unmistakably recall Vergil's scene together with its long legacy.

Like Prudentius, Vida used classical poetic materials to enact a move from pagan confusion to Christian enlightenment. ${ }^{52}$ By Vida's day, however, Christianity had left far behind its conflicts with classical culture. Christian culture could securely appropriate the products of earlier Greek and Roman civilizations with no fear that such valorization would abet a reversion to paganism. In light of Eclogue 4, to which Vida elsewhere alludes, Vergil himself had long been rehabilitated as an enlightened pagan precursor of Christianity. ${ }^{53}$

In this context, Vida's daring move seems not that daring at all. In the time of Prudentius, implicitly comparing the mother of god to the mythical wife of the founder of pagan Rome, Lavinia, could have been a touchy gesture, because of greater familiarity with the pre-Christian literary tradition and its continued cultural weight. But Vida fears no charge of blasphemy. His association of Mary with Lavinia only adds resonance and authority to his portrayal of the mother of Christ. ${ }^{54}$

51 I discovered this passage in Bruére $(1966,39)$ via the JSTOR search for "rose" and "lil." Translation from Gardner (2009).

52 Warner $(2005,134)$ writes that "the Aeneid supplies the means for the Christiad's readers to mark their progress from Vergilian falsehoods to Christian Truth."

53 (Kallendorf 1995, 59-62).

54 In addition to this example from Renaissance epic in Latin, Pramit Chaudhuri points out to me per litteras several instances of the roses and lilies topos in vernacular Italian epic of the period. In Boiardo's Orlando furioso, the poet uses the phrase "Tra le purpuree rose e i bianchi gigli" (6.22) to describe a locus amoenus. He uses it as well to describe female beauty $(7.28$, $10.95,10.96)$, in the last case with the lily changed for the white privet, as it is also in 7.11 , which resembles Vergil's lines most closely. Cf. 27.121, 32.13. Tasso in his Gerusalemme liberata has related phrases at 4.30 and 19.67. 


\section{Metaphysical metamorphosis: Marvell "The Nymph Complaining for the Death of Her Fawn"}

The 17th-century English metaphysical poet Andrew Marvell is perhaps most famous for his poem "To His Coy Mistress." He was also well-versed in classical literature, writing some of his earliest poems in Greek and Latin and even publishing “A Horatian Ode upon Cromwell's Return from Ireland.”55

Among Marvell's better-known poems is his "Nymph Complaining for the Death of Her Fawn." ${ }^{56}$ In 122 lines, a nymph laments the death of a fawn given to her by her beloved, a hunter named Sylvio who has abandoned her. She vows to bury her fawn and die soon after, having first constructed a marble tomb with a statue of herself weeping with the fawn at her feet.

In the springtime, the nymph tells us, the fawn stayed only in her garden, which was "so with roses overgrown, / And lilies, that you would it guess / To be a little wilderness" (71-74). The small white deer would nearly disappear in the white lily beds, and it would eat the roses "until its lips e'en seem to bleed" (84), after which it would again lay "its pure virgin limbs" in "whitest sheets of lilies cold" (89-90). "Had it lived long," she imagines, "it would have been / lilies without, roses within" (91-92).

Marvell does not use Vergil's Latin words, nor even his hexameter. Nor does he make any mention of a blush. Nevertheless, his scene belongs within the tradition Vergil began, not only because Marvell surely encountered it in his Latin reading. The English poet uses the marked pairing of roses and lilies along with mention of blood. And he joins these terms to the key themes of love and loss: the nymph's love for Sylvio and her fawn, and the (symbolically related) loss of both. The death of the fawn separately parallels the loss of the nymph's chastity and innocence, not least because of the imagery of the arrow piercing of the "virgin" fawn and drawing blood.

In the context of Lavinia's blush, despite the toll of the war to that point, the threat of blood and loss hang imminent. In Marvell's poem they are realized: the

55 On his Latin poetry, see Haan (2003). In his Faerie Queene, the first three books of which were published in 1590, Spenser had already taken over Vergil's imagery for blushing more than once: "And in her cheekes the vermeill red did shew / Like roses in a bed of lillies shed"

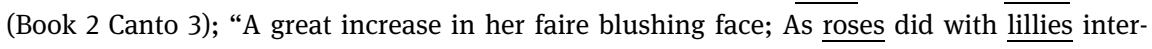
lace” (Book 5 Canto 3) (I owe these references to Prof. A. E. B. Coldiron).

56 Vergilian connection discovered by the JSTOR search, which led to Allen (1956), who discusses the theme of flowers and loss that Marvell draws from antiquity. 
bloodshed of the fawn's death is described, that of the nymph foreshadowed in her contemplated suicide. From all appearances, it would seem that Marvell had thoroughly absorbed, from Vergil or others, the associations of the two flowers, love, and loss, which he then translated from Latin epic into a romantic English idyll, further sharpening their symbolic associations. ${ }^{57}$

\section{Conclusions: poetics}

With his description of Lavinia's blush, Vergil created a lasting image that many other poets and authors took up for their own. Beauty, fragility, hope, loss, shame: all were combined into a powerful, flexible, and reusable formula. Some poets kept the core ideas. Ovid treated them with levity in his Amores. Marvell extended them for his own romanticizing purposes. Others retained the poignancy of the image but made it drive a positive message, as in Statius's celebration of marriage or the redemption of humanity and the classical tradition celebrated by Christian authors.

Among another set of authors, distinctive features of Vergil's image remain, but seem to derive from a larger conceptual and poetic vocabulary independent of Vergil or even to epic genre. In the Carmina Burana, the core concept of loss is simply deleted and the flowers used to express an erotic, blooming context that is fully joyful. In the case of Seneca's letters, we have simply the two flowers associated with loss through decadence. The image has lost its tie with the tradition and moved out in the wider world of writing where authors have found it.

\section{Conclusions: methods}

This study illustrates how we can use modern digital search tools to delineate a full, if not necessarily comprehensive, tradition of literary inheritance at the level of individual images and phrases. If we want to pursue this kind of research, we may hope in the future to streamline the process, so that rather than cobbling together passages with all the tools and sources employed here, scholars can more quickly map out a micro-tradition. ${ }^{58}$

57 Marvell's contemporary John Ford, in his 1633 play 'Tis Pity She's a Whore, Act 1 Scene 3 writes of a blush "The lily and the rose, most sweetly strange, / upon your dimpled cheeks do strive for change” (Enk $(1962,58)$ on Propertius Elegies 2.3.11-12).

58 See Coffee (2018, 205-223) for ideas about how this work might proceed. 
But do we want to pursue this kind of research? I would again answer "yes.” It offers significant advantages to understanding our texts: we can read any point in the micro-tradition relative to its predecessors and successors. To take the case of Prudentius, we find he was not only drawing his image of roses and lilies from Vergil, but also incorporating a long tradition of the reworking of Vergil's image. By reinterpreting a whole strand of literary inheritance, however small, Prudentius created an even more powerful gesture of subsuming and appropriating the classical tradition than had he only reworked a Vergilian passage. Looking forward, we find Prudentius disseminating a positive version of the motif later taken up by the Christian author Vida and possibly behind the secular celebrations of love of the Carmina Burana.

Another possibility opened up is to take the viral intertext itself as an object of study. What was it about Vergil's image that made it so durable and adaptable? Was its persistence predicated on the canonicity of Vergil's epic, or could language from less canonical works become similarly pervasive? How far out into the wider world of Latin, and other languages, can we productively trace the movement of a viral intertext? Somewhere around the border between figured and ordinary language, as we saw with Seneca? Answers to questions like these could give us a more concrete understanding of the functional dynamics of intertextuality. That would in turn allow us to measure the artistry of individual authors against better-articulated standards of what was possible within a genre or language.

\section{Bibliography}

Allen, D.C. (1956): “Marvell's ‘Nymph’”. English Literary History 23:2, 93-111.

Audano, S. (2012): Classici lettori di classici: Da Virgilio a Marguerite Yourcenar. Foggia: Il Castello.

Boyd, B.W. (1997): Ovid's Literary Loves: Influence and Innovation in the Amores. Ann Arbor: University of Michigan Press.

Brockliss, W.; Chaudhuri, P.; Lushkov, A.H.; Wasdin, K. (eds.) (2012): Reception and the Classics. An Interdisciplinary Approach to the Classical Tradition. Yale Classical Studies 36. Cambridge: Cambridge University Press.

Bruére, R.T. (1966): “Review Article: Virgil and Vida.” Classical Philology 61:1, 21-43.

Butler, H.E. (ed.) (1912): Propertius. London: Heinemann.

Cairns, F. (2005): “'Lavinia’s Blush' (Virgil Aeneid 12.64-70)”. In: D.L. Cairns (ed.): Body Language in the Greek and Roman Worlds. Swansea: Classical Press of Wales, 195-213. Camps, W.A. (ed.) (1961): Propertius Elegies: Book I. Cambridge: Cambridge University Press. Chaudhuri, P.; Dexter, J.P. (2017): "Bioinformatics and Classical Literary Study". Journal of Data Mining and Digital Humanities. arXiv:1602.08844 [cs.CL]. 
Coffee, N. (2012): “Intertextuality in Latin Poetry.” In: D. Clayman (ed.): Oxford Bibliographies in Classics. New York: Oxford University Press.

Coffee, N. (2018): “An Agenda for the Study of Intertextuality”. TAPA 148:1, 205-223.

Di Cesare, M.A. (1964): Vida's Christiad and Vergilian Epic. New York: Columbia University Press.

Enk, P.J. (ed.) (1962): Sex. Propertii elegiarum, liber secundus. Lugduni Batavorum: A.W. Sijthoff.

Fairclough, H.R.; Goold, G.P. (eds.) (2000): Aeneid. Books 7-12. Appendix Vergiliana. Cambridge, MA: Harvard University Press.

Gardner, J. (ed.) (2009): Marco Girolamo Vida: Christiad. I Tatti Renaissance Library. Cambridge, MA: Harvard University Press.

Gummere, R.M. (1925): Seneca. Epistles 93-124. Volume 6. Cambridge, MA: Harvard University Press.

Haan, E. (2003): Andrew Marvell's Latin Poetry: From Text to Context. Bruxelles: Latomus.

Kallendorf, C. (1995): "From Virgil to Vida: The Poeta Theologus in Italian Renaissance Commentary". Journal of the History of Ideas 56:1, 41-62.

Keil, H. (1961): Grammatici latini ex recensione Henrici Keilii. Hildesheim: G. Olms.

Ker, W.C.A. (1968): Martial Epigrams. Volume 1. Cambridge, MA: Harvard University Press.

Martindale, C. (2006): “Thinking through Reception”. In: C. Martindale; R.F. Thomas (eds.): Classics and the Uses of Reception. Oxford: Blackwell, 1-13.

Martindale, C.; Thomas, R.F. (eds.) (2006): Classics and the Uses of Reception. Oxford: Blackwell.

Migne, J.P. (1857): Patrologia Graeca. Paris: Migne.

Miller, F.J.; Goold, G.P. (eds.) (1984): Ovid Metamorphoses Books IX-XV. Cambridge, MA: Harvard University Press.

Mozley, J.H. (ed.) (1939): Ovid II: The Art of Love and Other Poems. Cambridge, MA: Harvard University Press.

Peiper, R. (ed.) (1886): Decimi Magni Ausonii Burdigalensis Opuscula. Leipzig: Teubner.

Platnauer, M. (ed.) (1922): Claudianus. London: Heinemann.

Quinn, K. (ed.) (1973): Catullus: The Poems. London: Macmillan.

Schmeller, J.A. (1847): Carmina burana. Lateinische und deutsche Lieder und Gedichte einer Handschrift des XIII. Jahrhunderts aus Benedictbeuern auf der K. Bibliothek zu München. Stuttgart: Literarischer Verein.

Shackleton Bailey, D.R. (ed.) (2004): Statius. Thebaid. Books 1-7. Cambridge, MA: Harvard University Press.

Showerman, G.; Goold, G.P. (eds.) (1977): Ovid. Heroides and Amores. Cambridge, MA: Harvard University Press.

Skutsch, O. (ed.) (1985): The Annals of Quintus Ennius. Oxford: Oxford University Press. Tarrant, R.J. (ed.) (2012): Aeneid. Book XII. Cambridge Greek and Latin Classics. Cambridge: Cambridge University Press.

Thomas, R.F. (1986): "Virgil's Georgics and the Art of Reference". HSCP 90, 171-198. Thompson, H.J. (ed.) (1949): Prudentius. Volume 1. Cambridge, MA: Harvard University Press. Warmington, E.H. (1988): Remains of Old Latin. Volume 1. Ennius and Caecilius. Cambridge, MA: Harvard University Press.

Warner, J.C. (2005): The Augustinian Epic, Petrarch to Milton. Ann Arbor: University of Michigan Press. 